\title{
Between the Permitted and the Forbidden: The Politics of Holocaust Representation in The Unvanquished (1945) ${ }^{1}$
}

\author{
Olga Gershenson
}

In October 1945, The Unvanquished premiered in Moscow theaters. The Nazi crimes against the Jews that would later be known as the Holocaust were at the core of the film. One of the central characters was a Jewish doctor played by the great Yiddish actor Veniamin L'vovich Zuskin. A key scene in the film was the mass execution of Jews by an SS unit. This scene was filmed on location, in Babii Iar, a place that came to symbolize the Holocaust in the Soviet Union. For its time and place, the film was remarkable for its deeply sympathetic treatment of the Jewish catastrophe.

Because of this treatment, The Unvanquished has recently attracted scholarly attention. According to the Russian critic Miron Markovich Chernenko, The Unvanquished was the first film to depict the Holocaust on Soviet screens, and one of the first such films worldwide. He points out that several recurrent motifs in the representation of the Holocaust, such as images of Jews led to their death and characters of righteous gentiles, appeared for the first time in this film. ${ }^{2}$ Film scholar Jeremy Hicks also approaches The Unvanquished as the first Holocaust film and considers it within the broader context of both the historical events of the Holocaust on Soviet territory and representations of the Holocaust in other films. Hicks provides a nuanced analysis of the film and explains why it did not become a part of the Holocaust film canon even though it was the first Holocaust film. ${ }^{3}$ Elena Baraban reads The Unvanquished as a film dealing with two taboo Soviet topics: Jews and prisoners-of-war, both excluded from "the big family" of the Soviet people. ${ }^{4}$

Despite their different readings of the film, what underlies these scholars' interest is the fact that The Unvanquished, a film representing the Nazi mas- 
sacre in Babii Iar, was released in 1945 and was positively received by Soviet critics-it was even chosen to represent the USSR at the Venice Biennale in 1946. ${ }^{5}$ Seemingly, this story contradicts the widespread assumption about the Soviet silencing of the Holocaust. What does The Unvanquished reveal about the Soviet treatment of the Holocaust? I argue that the history of the production and reception of The Unvanquished demonstrates Soviet ambivalence about the Holocaust and a profound confusion about Holocaust representation. This history captures the moment of indeterminacy in Soviet discourse about the Holocaust when it was still being formulated, and thus it gives us an insight into the discourse-in-the-making.

As historians Karel Berkhoff and Kiril Feferman show, during the war Soviet attitudes vacillated between the allowed and the forbidden, complicated by the positioning of the Holocaust simultaneously as a matter of Jewish history and a part of the general Soviet war history. Throughout the war, there was no consistent policy regarding representation of the Holocaust, but despite the inconsistency the tendency was towards silencing, universalization, and externalization of the Holocaust. ${ }^{6}$ These tendencies intensified over time: if in the early stages of the war, the Holocaust was a permissible topic (mainly because it was a matter of foreign policy), starting in 1943 the Jewish character of the Holocaust was increasingly downplayed.7 And nevertheless, this was just a tendency. Berkoff emphasizes that "even as late as August 1944 there was no top-level decision, in writing or not to fully omit Jews from media reports about the victims of the Nazis."

Despite the tendency towards silence about the fate of Jews during the war, the Jewish tragedy could still be seen in artistic productions as late as 1948 , and it was directly referenced in legal discourse (mainly in the reportage of the Nuremberg Trial). ${ }^{9}$ Taken together, this amounts to a contradictory and ambivalent picture. These tensions and ambivalence with regard to the interpretation of the Jewish tragedy permeate The Unvanquished on several levels-the film's narrative, as well as the film's professional and critical reception.

\section{How a Soviet Novel Turned into a Jewish Film}

In 1943, Pravda serialized Boris Leont'evich Gorbatov's novel The Unvanquished, about the fate of a Ukrainian family during the war. ${ }^{10}$ The action takes place in an occupied Ukrainian town, where Taras lives with his extended 
family-his wife, his young daughter, and two daughters-in-law with children. His two sons fight in the Red Army and in the partisan movement. The novel was published when the war was still raging, but it ends on a happy note, with the liberation of the town. Among other minor characters there is an old Jewish man-a lonely doctor, who used to treat Taras's children and grandchildren. In the novel, he appears only twice: first, when Taras runs into him in the street, and second, when the doctor, along with other Jews, is marched to his death. Another Jewish character mentioned in passing is a little girl, hidden by various people in their houses, until the Nazis capture and presumably kill her.

The novel, surprisingly readable for 1943 Pravda, was a big hit (in the same year, it came out in book form and had dozens editions in the 1940s-1980s), and soon after its publication the great Soviet director, Mark Semenovich Donskoi, turned it into a film. Donskoi was at the peak of his fame: his then most recent film, Rainbow (1943), the story of a Ukrainian partisan woman, was an enormous success. Rainbow won not only the Stalin Prize but also recognition of American critics, and it was allegedly understood by Franklin Roosevelt without translation. ${ }^{11}$ Donskoi was ethnically Jewish, but he was neither part of the Soviet Yiddish cultural establishment, nor did he identify publicly with the Jewish people or feature Jewish themes in his work. For instance, even though Rainbow takes place in occupied Ukraine, there is no mention of Jews on screen. The Unvanquished was a considerable departure from that position.

The transformation of the novel entailed more than the development of a Jewish plotline. For 1945 Soviet Union, the film is unusually redolent with Jewish references. This was a conscious choice: writing about the film shortly after its completion, Donskoi keeps emphasizing its Jewish characters, especially Dr. Fishman, whose story is intertwined with that of Taras's family. ${ }^{12}$ Donskoi puts the Jewish doctor front and center: the novel opens with a scene of mass escape from town; the film opens with a close-up of Dr. Fishman. He is treating Taras's sick granddaughter to the sound of bombing in the background. Dr. Fishman cuts a sympathetic and even endearing figure. He is portrayed as a member of the intelligentsia-a balding professor, with a beard and white hair, in a suit and a tie. He speaks polite, hyper-correct Russian, in a voice that remains calm even at the most dramatic moments. His suffering is endured stoically. He doesn't lose his sense of humor-attending to his little patient under the whistling missiles, he playfully recites with her a children's 
poem about kind Doctor Aibolit (a Russian Doctor Doolittle, a character beloved by generations of Soviet children). He is Doctor Aibolit himself.

When the doctor leaves Taras's house, the tracking shot shows his lonely figure walking away into the devastated landscape, balancing precariously on piles of rubble, and disappearing into the smoke. This shot visually echoes the end of Jewish Luck (1925), when Menachem-Mendel (Solomon Mikhoels) walks away into a distance. This shot establishes that, like Menachem-Mendel, Dr. Fishman is a Wandering Jew.

After this initial interaction, Taras and Dr. Fishman meet twice more. Each encounter with the doctor constitutes an important step in the transformation and growth of Taras's character. The first such meeting takes place at a street market, where Taras runs into Dr. Fishman, who is offering his meager possessions for sale. Tracing Taras's gaze, the camera zooms on a Jewish star on the doctor's sleeve. Next to the doctor is his granddaughter, a sad and serious child with big eyes who is clutching a doll to her chest. They both are silent and motionless among the hustle of the marketplace. The doctor points to the girl: "This is my granddaughter-the most precious of what I have left." Importantly, in the novel, the doctor had no family or relations. In the film, the doctor has a granddaughter, and his line, "what I have left," hints at the prior loss of his family. Perhaps, he, like Taras, was once father and grandfather to a larger clan.

As the Germans raid the market, panic ensues, and people run away, among them the doctor. In the next shot, he is hiding in an entryway, disheveled but still clutching the girl and her doll to his body. When Taras finds them, he invites the doctor to his house. The doctor declines, but gives his granddaughter to Taras. The little Jewish girl is adopted by Taras's family, and Taras takes the place of her Jewish grandfather.

The most important encounter-and a central scene of the film-occurs when Taras and his factory comrades are burying a friend shot by the Germans for his refusal to cooperate. The funeral encounters a wretched procession of Jews with motley luggage, marched by a German convoy with dogs and guns. As the processions draw near, Taras recognizes the doctor among the figures in the convoy, approaches him, and bows. "Is this to me?" wonders the doctor. "To you and to your suffering," replies Taras (serving probably as a director's mouthpiece). "Thank you, Human Being," says the doctor, echoing Maxim Gorky's glorifying use of the word chelovek (human being) so familiar to Soviet audiences. The scene ends as the procession resumes to a 
klezmer-like melody. Later, the motif of a funeral also appears in Commissar (1967/1987), in a flash-forward when a procession of Jews carrying a coffin are marched to their death.

In the novel, Taras had a similar conversation with the doctor during their chance encounter in the street. In the film, Donskoi gave this conversation much more gravitas by moving it to take place on the doctor's way to death. Donskoi's script also added a reference to Gorky (whose work preoccupied Donskoi throughout his life), envisioning Jewish suffering as the universal human tragedy.

In the novel, the mass execution is depicted in a single sentence: "The Jews were shot somewhere outside of the town." In the film, the execution is depicted graphically and emphatically. Although, as Jeremy Hicks notes, the scene does not represent the execution with historical accuracy, it nevertheless pays an important tribute to the death of millions of Soviet Jews killed near or around their hometowns. ${ }^{13}$ Moreover, in the novel, and in earlier versions of the script, the town is named Kamennyi Brod; in the later versions the town is left unnamed. Thus, even though the scene is filmed in Babii Iar-the most symbolic Holocaust site in the Soviet Union-it can be read as representing any massacre of Jews in any-and hence every-town. ${ }^{14}$ This scene is undoubtedly the center of gravity in the film. ${ }^{15}$

Representing mass killing on screen for the first time must have been a challenge for the filmmaker, as there were few models to rely on. Donskoi chose to draw on images of massacres in Sergei Eisenstein's films, which were already classics. In addition to the remarkable synchronization of music and on-screen action characteristic of Eisenstein, ${ }^{16}$ the first shots of the scene, when the camera closes in on children, women, and old men huddled in the ravine, are reminiscent of similar shots in the scene of the Pskov massacre in Alexander Nevsky (1938). In Alexander Nevsky, however, the Germans are killing ethnic Russians. In The Unvanquished, the victims about to be murdered are typecast to look Jewish. Among others, a bearded old man who looks like a biblical patriarch clutches to himself a young boy with curly hair (Donskoi's own son was cast in this role ${ }^{17}$ ). This shot is intercut with a close-up of Dr. Fishman, who concentrates on his silent prayers, rocking his head slightly, as the Nazis yell out orders in the background. When the shooting starts, the camera intercuts between a clouded sky and the scene of the massacre, and music grows to crescendo. In another tribute to Eisenstein, the line of Nazis who advance towards the Jewish crowd fir- 
ing machine guns is reminiscent of the Cossacks in the famous Battleship Potemkin (1925) scene. ${ }^{18}$

The camera pans over the Nazi commanders who are calmly watching the execution, and then over the ravine, full of white smoke, with corpses visible in the foreground. The scene ends with a shot of a lone dead tree with a scarf caught on its branches. Although the symbolism of the image is universal, it has a particular Jewish resonance. On stage at the State Yiddish Theater, this image was used as a symbol of Judaism. It first appeared in Wandering Stars (1941). Later, in Tumultuous Forest (1947), the scarf became the scrap of a tallit (Jewish prayer shawl). ${ }^{19}$ Another tallit was depicted blowing in the wind on a concentration camp fence in the painting by Zinovii Tolkatchev "Taleskoten," made in 1944 during the liberation of the Majdanek Extermination Camp. ${ }^{20}$

The execution is the end of Aron Davidovich Fishman's life, but it's not the end of the Jewish people in the film. The doctor's granddaughter was saved by Taras. On screen, the girl is shown happily playing with Taras's grandchildren, even though she has to be hidden during the Nazi raid. Eventually, the Nazis find her, still sleeping peacefully in her hiding place, clutching the doll to her chest. Her execution is only prevented by an undercover partisan posing as a politsai-a local Nazi collaborator-who whisks her away to safety. Again, this entire subplot was added by Donskoi. In the novel, the anonymous girl is hidden collectively-every night she is passed to another family. It is only by chance that she is captured in Taras's house; he is not solely responsible for her. Moreover, in the novel, the girl is probably killed. But for Donskoi it was important that the girl live on. With her doll, she is a little Madonna-both a reference to a powerful Christian religious symbol, and a promise of the future of the Jewish people. The Madonna-like figure is not uncommon in Donskoi's films: in a key scene in Rainbow, the female protagonist is persecuted, tortured, and led away by a convoy while holding a child in her arms, the same way the little Jewish girl holds her doll.

Despite such parallels, Jews and non-Jews are represented in the film with striking differences. In contrast to Taras's sons and comrades, who are actively resisting the Nazis, the Jews passively walk towards their death. Taras and his sons are men of action-grounded in their household (in the scenes at Taras's house), in their physical labor (in the scenes at a factory), and in their cultural capital (Taras's grandchild keeps reading from Gogol's Taras $\mathrm{Bulba}$ ). Dr. Fishman is homeless on-screen, always with his bag and his cane, 
unprotected, in need of shelter, a learned but powerless man. In the patriarchal universe of Stalinist film, power belongs to men, and women are to be shushed or saved. In that context, it is significant that in The Unvanquished the Jews, as represented by an old man and a little girl, are emasculated. ${ }^{21}$ This creates a dichotomous story of the Great Patriotic War, in which all victimhood is relegated to the Jews, and all heroism to the non-Jewish Soviet people (be they Ukrainians, Russians, or other titular nationalities). Obviously, there are no collaborators or traitors among those heroes.

And yet, not everything is that simple. Once Jews are gone, others take their place-at least that's what Donskoi's visual language suggests. Instead of the Wandering Jew-a doctor with his bag-Taras takes to the road. Importantly, in the novel, Taras needs to leave in order to find food, and his epic journey, including his encounters with people from all walks of life, is narratively justified. In the film, it is not entirely clear why he embarks on his journey. Taras says he is going to search for "the un-ravaged land" (nerazorennaia zemlia), which calls to mind "the promised land" (obetovannaia zemlia), an obvious Jewish reference. His lonely figure trekking through various landscapes is reproduced multiple times to show the length of his journey. On his way, Taras is joined by more and more such wanderers, until they walk in a procession like that of the Jews we've seen before. Their identities are muffled: Taras is indistinguishable from others, and it seems that the whole country, depicted by Donskoi as a vast landscape, is homeless. Now the whole people turn into wandering Jews. Their makeshift camps set up amidst the devastated landscape create striking anti-utopian images, especially in contrast to the cozy interior setting of Taras's house. All these changes to the novel-the development of the Jewish characters' subplot, the addition of the execution scene, and this reconceptualization of Taras's journey-had far-reaching consequences for the film's professional (read: censorial) reception.

\section{Professional Reception: Ambivalent Censors}

On June 21, 1945, the film was discussed at the meeting of the Artistic Council of the Film Committee.22 The head of the Committee, Ivan Grigor'evich Bol'shakov, chaired the meeting. Among the members were such figureheads of Soviet culture as Konstantin Mikhailovich Simonov, Ivan Aleksandrovich Pyr'ev, Sergei Appolinar'evich Gerasimov, Mikhail Il'ich Romm, Igor Andreevich Savchenko, Sergei Mikhailovich Eisenstein, Nikolai 
Pavlovich Okhlopkov, Boris Andreevich Babochkin, and Dmitrii Dmitrievich Shostakovich. ${ }^{23}$ Gorbatov and Donskoi were also present.

The discussion was far from smooth. The important historical context for the film's reception was already established by Simonov, a Soviet cult poet and a scriptwriter of the popular war-time melodrama Wait for Me (1943), in his introductory remarks: "I went to see it with a certain trepidation ... I was afraid to be biased because now one doesn't want to see and read about horrors of the war, and about frightening and difficult wartimes." ${ }^{24}$ This is an understandable sentiment, given that the committee saw the film just a month after the long-awaited victory, a time of great euphoria. Despite his reservations, Simonov identified The Unvanquished as a "historic picture," and talked about its importance for the collective memory of the war crimes. He then shared this recollection:

Once, in the streets of Prague, I saw the Czechs herding a large number of Germans through town. And they were treating them poorly.... At first, I felt this sympathy for Germans, and I stopped the car and wanted to do something.... But we shouldn't forget what happened in this war. And when I saw this film, the scenes where they march the Jews-I recalled that moment in Prague, and I thought that yes, I did the right thing by first stopping the car, and then by driving on. Let them drag the Germans however they want!

Simonov continued, "We have to keep reminding [ourselves] about this dark history." ${ }^{25}$ From the outset, Simonov placed the Jewish tragedy and its memory at the center of the discussion. The debate that followed explicitly dealt with the larger question of the representation of the Holocaust on Soviet screens.

Indeed, the film proved divisive mainly because of its treatment of the Jewish topic: the main controversy was about the execution scene, which some committee members interpreted as privileging the Jewish tragedy above overall Soviet losses. The second point of contention, much more subtly connected to a Jewish topic, emerged in the discussion of Taras's character. The committee split over the two issues: Romm and Simonov headed the faction that advocated for the film, Okhlopkov and Babochkin led the opposition. How could cultural officials be anything but confused about how to represent the Holocaust if, indeed, they were dealing with the first cinematic depiction 
of the mass killings? There were no ready models, and, more importantly, no clear party line on the matter.

In his remarks, Babochkin (most famous for his lead role in the Soviet cult movie Chapaev) argued that the film was a failure, and among its main problems he listed the execution scene. Paradoxically, Babochkin first admitted that it was a powerful scene, but then completely denounced it: "I am convinced that this scene is unacceptable, because it does not have any elements of art. There is grotesquery (guignol), which cannot leave one indifferent, but it is not art. I am under the impression that we don't have the right to show to our audiences scenes like that." He continued, "audiences will not accept this picture." 26 The "representative of the people" (i.e. not a cultural producer himself) Major-General M. R. Galaktionov backed up Babochkin:

Comrade Babochkin pointed to the execution scene. The thing is that if this scene is presented then it needs to be done $100 \% \ldots$ But here, it is presented "halfway." If it was presented realistically, if it showed how people run in horror, how children cry, women wail, how wounded writhe with pain and so on-then it would have been deeper, more convincing. And one more thing: if it showed some sort of resistance... But here people stand calmly, timidly, and wait for their lot-to be shot... This exactly conveys stereotypical ideas about the Jewish people, who submissively accept their fate.

It might appear that Galaktionov is concerned with the more positive-and less stereotypical-representation of Jews, but in the end he comes to the same conclusion as Babochkin: "This scene of execution should be portrayed better, perhaps just leading up to it but not showing the actual shooting... This scene here is a $100 \%$ failure, and since it is so, it should be taken out completely." ${ }^{27}$ This reaction, once again, shows a profound confusion about the scene-how can the Jewish massacre be represented? The discussants err on the side of caution: since there is no clear model, it is safer to simply take the scene out.

Film director Savchenko was silent at the meeting, but he wrote a review of The Unvanquished, potentially in preparation for its discussion by the Artistic Council. Ironically, Savchenko was one of the forefathers of the Soviet "ethnic" film, and yet Savchenko raises similar concerns in his unpublished review: "The facts of the physical extermination of several million Jews are so 
frightening, so inhumane, and so incomprehensible to a normal person, that this subject shouldn't be discussed superficially. Either it needs to become the subject of a separate picture, or it shouldn't be mentioned at all." Savchenko is equally incensed at the portrayal of Jews as "a submissive suffering herd," which according to him entirely misrepresents active and heroic Soviet Jews. He goes as far as calling the film an "undeserved insult to Jewish people." ${ }^{28}$ The execution scene was a problem for him and others, because it portrayed the murder of innocent people outside the trope of Soviet-style heroism.

Notably, the silent Savchenko and the vocal critics apparently had the best interests of the Jewish people in mind-except for their conclusions. Since they all found Donskoi's representation of Babii Iar deficient, they felt that the Jewish tragedy should not have been represented at all. The critics felt great discomfort about the portrayal of Jewish suffering, because, with keen political intuition, they grasped that it was counterproductive both to the optimistic post-war zeitgeist and to the emerging party line.

As mentioned above, by 1945 Soviet policies regarding the events of the Holocaust already favored silencing, universalization, and externalization. ${ }^{29}$ If there was any discussion of the Holocaust in the media, it was focused on resistance, not suffering. ${ }^{30}$ The scene of an execution of Soviet Jews on Soviet territory did not sit well with this trend. And yet, none of these policies were formulated clearly-the discourse on the war and its victims had not ossified yet. In light of these circumstances, it is not surprising that the committee members were conflicted over Donskoi's treatment of Jewish suffering.

The camp of the film's advocates was represented most prominently by Mikhail Romm. (This was neither the first nor the last time Romm would act as an advocate of Jewish cultural producers or their work). ${ }^{31}$ He first called such criticism of the film "unwarranted" and "unjust" and then presented his own argument: "I don't agree with Babochkin that the execution scene should not be shown... If during these years 3.5 million Jews [sic] in Europe were exterminated and we haven't yet said a word about it, haven't represented it in our films, and if in this picture, a mass execution is shown in one scene, I am convinced that this scene needs to stay there." He continued his advocacy: "Despite some shortcomings, this is a necessary film, it has to be released, and people both here and abroad will see this picture."32 Notably, Romm cites an incorrect number of the Jewish victims. Even though the number six million had already been mentioned by Il'ia Ehrenburg in $1944,{ }^{33}$ it was not widely circulated in the USSR before 1955, following repeated publications of the 
Nuremberg Trial documents. ${ }^{34}$ Romm also externalizes the Holocaust. He talks about an execution of Jews "in Europe," underplaying the fact that a great many executions took place on Soviet soil. And yet, Romm makes a strong case for a need to represent Jewish suffering and leave the execution scene in.

The execution scene was not the only hurdle. Other committee members criticized the film for its overall development of the Jewish plotline as compared to the novel. Pyr'ev, a film director who in 1943 made a speech about "a lack of true Russianness in our cinema," ${ }^{35}$ was particularly upset about the great emphasis on the character of the doctor, which, he added, "clearly, is done on purpose." To that, Donskoi shouted from his place: "Yes!" Pyr'ev continued with his criticism, "Comrade Romm here mentioned 3.5 million Jews who perished. It's true. And it is true that this film needed to be made. But when all the peoples of our Motherland are concerned, all of them... then why separate [Jews] in contrast to the novel?" ${ }^{36} \mathrm{Pyr}^{\prime} \mathrm{ev}$ advocated for a particularly Soviet approach: the mass murder of Jews should not be separated into its own category, but should be part of universal Soviet suffering. Indeed, universalization was exactly the party line regarding the Holocaust for years to come. Pyr'ev's words capture a moment when this approach was being formulated.

Another debate evolved around the character of Taras. In the film, Taras is an ethnic Ukrainian, but the following discussion at the meeting was still about Jews and Jewish representation. The topic was introduced by actor and director Okhlopkov, when he criticized Buchma's performance as Taras, which he interpreted as overly emotional. Okhlopkov called Taras "a Spaniard in Africa" with "burning eyes." According to him, Buchma's Taras is "a kind of African, and everything about him is breathing fire." ${ }^{37}$ Okhlopkov was not alone in this particular criticism. The choir director V.G. Zakharov complained that Taras is "wild and passionate." ${ }^{38}$ Film director Gerasimov noted the character's "African passions." 39 Why were Buchma's expressive facial features and body language so disagreeable to the committee members that they reacted with over-the top orientalist imagery? Okhlopkov's own words provide an answer:

I saw this once-a car is driving on the road, and is unable to pass two shtetl Jews who are walking right in front of it-with their hands [blocking the road] on the right and [blocking the road] on 
the left-they are talking. Jews have that kind of body language. I also use gestures, but for Ukrainians it is atypical. They don't use this kind of body language... Ukrainians are in general very calm people; when it is necessary they can heat up, but to burn all the time like Taras-they don't do it. Here he looks like an African, or some sort of Spaniard. ${ }^{40}$

In fact, Okhlopkov doesn't like Taras's body language because it reminds him of the shtetl Jews from his anecdote. And all these "Africans" and "Spaniards" are just code words, indicating foreignness or otherness usually associated with Jews. Okhlopkov's anxiety regarding Buchma's character doesn't come out of nowhere. Buchma, in fact, grew up in Galicia, was familiar with Jewish life, and was known for his brilliant portrayal of several Jewish characters in the earlier Soviet films On the Eve (1928, based on Gambrinus by A.I. Kuprin) and Five Brides (1929). ${ }^{41}$

If Okhlopkov and others were critical of Taras's character because they saw him as a kind of Jew, then another point of contention can be explained too: nearly all the committee members, both advocates and opponents of the film, were critical of Taras's journey in the film as "incomprehensible." As Okhlopkov correctly pointed out, in the novel Taras has to take to the road to find food for his starving family. In the film, his journey is seemingly unmotivated. Moreover, his search for "the un-ravaged land" gives Taras's journey symbolic meaning derived from Judaism, which made committee members uncomfortable. Gerasimov, who was also critical of the journey, called it "the Biblical travels of Taras" and rattled against the "naïve symbolism" of the film. ${ }^{42}$ Himself a closeted Jew throughout his career, Gerasimov was the only one who understood that Donskoi took away the perfectly reasonable and mundane justification of the journey in order to give it a symbolic dimension and to elevate it to the level of biblical parable. In the narrative logic of the film, Taras himself becomes a wandering Jew, an ambivalent symbol of persecution and perseverance.

The discussion of the film came to a stalemate, with one camp advocating for its release, and another voicing forceful opposition. A surprising remark by Eisenstein, who had remained quiet during the entire discussion, saved the day. When Okhlopkov suggests that not only the film be rejected, but even the script be rewritten and the film made anew, Eisenstein quipped, "But it's only in bad dreams that there can be such a punishment!" ${ }^{33}$ Everyone 
laughed, and somehow this resolved everything. Eisenstein's support is not surprising. His solidarity with the Jewish people was evident both in his activity with the Jewish Anti-Fascist Committee, and in the widely circulated anecdote that Eisenstein said about himself that although he was not Jewish, he had "a bit of a Yid" in him (s prozhid'u). ${ }^{44}$

After the laughter died out, Bol'shakov, who had also been silent up until that moment, simply dismissed the suggestion to re-make the film, despite Babochkin's and Okhlopkov's still virulent opposition. Bol'shakov then recommended the film for mass release, with minor revisions. It is hard to know for sure what led to such a dramatic turn, and to Bol'shakov's decision. Perhaps Eisenstein's authority was much greater than Babochkin's and Okhlopkov's taken together-at the time, Eisenstein's star was still shining brightly (this was before the 1946 banning of the second part of his Ivan the Terrible). Or maybe Bol'shakov knew something that Babochkin and Okhlopkov did not. Either way, Bol'shakov aligned himself with the film's advocates and his choice saved the film. Once again, the controversy demonstrates the ambivalence in Soviet policy regarding the representation of the Holocaust.

The meeting concluded with a resolution: “The novel's adaptation to film is paler than the original." The problem was that the authors "got carried away with the development of the secondary characters" (read: Jewish). Still, the text praised the mastery of the director in the scene identified as "the execution of peaceful residents" (a Soviet euphemism of choice for Jews). The text also lavished praise on Zuskin and Buchma for their performances as the doctor and Taras (who is described as "a complex character"). The ultimate resolution was to permit mass release. ${ }^{45}$

The deliberations of the Council reflected the ambivalence of the Soviet policies towards the Holocaust at the time. During the war, the Soviet attitude vacillated between the allowed and forbidden, complicated by the positioning of the Holocaust simultaneously as a matter of Jewish history and a part of the general Soviet war history. Although there was no consistent policy regarding the representation of the Holocaust during the early stages of the war, by 1944-45 the Holocaust was increasingly silenced. And yet, it was still present in both artistic productions and legal discourse. No wonder that Jewish suffering became such a bone of contention at the Council meeting. The members were confused about the party line. Is it permissible to show murdered Jews, and if yes, how? Therefore, the film's opponents made such 
contradictory pronouncements. While recognizing Jewish tragedy, they also voted against the execution scene and against explicitly Jewish characters, labeling them "a misrepresentation."

\section{Critical Reception: Confused Critics}

Released in October 1945, The Unvanquished was greeted by a number of overall positive reviews, which especially praised Zuskin and Buchma. The film's media reception, however positive, nonetheless reflected the already familiar confusion and ambivalence over representation of the Holocaust. The Jewish topic proved to be most controversial. Controversy arose even over the way of addressing it: some reviewers mention Jews verbatim, some refer to them euphemistically.

Only one review (in Sovetskoe iskusstvo) chose to avoid Jewish references completely, without even mentioning Zuskin. ${ }^{46}$ Not coincidentally, this was the most critical review of the film, pointing out its many shortcomings, while giving lukewarm praise. Most of other reviewers in one way or another dealt with the Jewish topic, without using the word "Jew" explicitly. A review in Moskovskii bolshevik described the scene of the last meeting between Taras and the doctor in great detail, noting that it "embodies a lofty idea of national equality and brotherly respect among Soviet people" in contrast to "fascist hatred and racist obscurantism." ${ }^{47}$ This hinted at Nazi antisemitism without actually spelling it out.

Similarly, the major newspapers Izvestiia, Vecherniaia Moskva, and Trud praised the doctor's character as one of the most memorable and significant in the film, especially in comparison to the novel. ${ }^{48}$ Izvestiia commended the powerful scene of mass execution. Trud mentioned Babii Iar and Trostianets (a place of mass executions of Jews near Minsk), but carefully called it "a place of mass execution of the populace." Thus, even though these reviews referred to the events of the Holocaust, the reviewers never mentioned anything Jewish directly. Their message might have been coded, but it was still clear. A review in the most authoritative newspaper, Pravda, echoed similar themes. ${ }^{49}$ The reviewer praised Zuskin but was critical of the doctor's "submissiveness." Pravda also did not approve of the execution scene: "On screen, our people go to their death submissively, but from real life experience we know that in such cases even the timid ones would rip bricks out of pavement and throw them at their murderers." Here the reviewer raised the much 
debated question of Jewish resistance (or lack thereof), and yet he completely evaded direct Jewish references.

Some reviews did bring up the Jewish topic, at least in passing. Discussing the doctor's character, Moskovskii komsomolets pointed out that he was murdered only for being a Jew (the reviewer scolds his portrayal as "doomed"). Krasnyi flot mentioned the Nazi persecution of the "little Jewish girl."

But two reviewers, I. Sokolov (Komsomolskaia pravda) and I. Kruti (Literaturnaia gazeta), specifically focused on the Jewish themes in the film. Sokolov discussed every instance in which the Jewish topic is treated in the film. He pointed out the Star of David on the doctor's sleeve, which marks him as a Jew. With great sympathy, he described both the scene of the little Jewish girl's capture, and the last meeting of Taras with the doctor, again not shying away from the Jewish content. ${ }^{51}$ Similarly, when Kruti praised the image of the two death processions coming toward one another, he described one of them as "procession of Jews, herded towards their execution at Babii Iar." Moreover, unlike some other reviewers, Kruti appreciated the doctor's character and saw in it an alternative model of courage: "V. Zuskin, with his customary precise and unobtrusive artistic mastery, creates an image of a great intellectual and moral power. He is not a victim, but a judge. This man goes towards his death unvanquished, as those who remain alive with weapons in their hands are unvanquished." ${ }^{52}$

This warm reception should have guaranteed the film's wide circulation and long run, especially during a time when few films were made. However, after its widely publicized premiers, The Unvanquished did not stay in theaters for long. ${ }^{53}$ Even as the film was shown at the Venice Biennale, its screening at the Mariánské Lázně International Film Festival was substituted at the last moment with a Stalinist tableau, The Vow (1946). ${ }^{54}$ After Zuskin's arrest in 1948, The Unvanquished disappeared from screens completely. However, even then it was not scratched out from Soviet film history. In 1948, Bol'shakov (who had served as chair of the Council meeting) published a brochure: Soviet Cinematic Art During the Years of the Great Patriotic War. He dedicated a generous two pages to the account of The Unvanquished, praising mainly its portrayal of heroism and resistance of the Soviet people in "proletarian Donbass." Zuskin is never mentioned, although amazingly Bol'shakov praises such "scenes as the execution of peaceful citizens, the raid at the market, and the journey in search of bread" as "well-made by the director and actors." ${ }^{55}$ Like most newspaper reviewers, Bol'shakov here talks 
about the Jewish scenes in the film, without ever identifying them as such. Even in the 1950 edition of the same brochure (re-issued mainly to add a few jabs at "rootless cosmopolitans"), a discussion of The Unvanquished remained in place, and did not change in tone. ${ }^{56}$ The film was never ostracized, but it was not endorsed either.

In sum, the film's reception reflected the ambivalent Soviet policies of the time, when the topic of the Holocaust was neither completely suppressed nor fully acknowledged, but vacillated in the grey area between the allowed and the forbidden. Its history-from the publication of the novel in Pravda, through its transformation into a film and the subsequent battle at the Artistic Council meeting, to its inclusion into the official party brochure-today provides insight into the shifting Soviet cultural politics regarding the Holocaust and its representation. ${ }^{57}$

In the 1960s, Soviet audiences had a chance to see The Unvanquished on TV. ${ }^{58}$ However, in contrast to the other Donskoi classics shown in their entirety, only excerpts from the film were allowed (it is easy to guess which excerpts were excluded). The Unvanquished returned to Russian audiences only relatively recently, when it was released on VHS and DVD. And so, decades after it was made, the film was salvaged from obscurity, and today occupies its due place alongside other Soviet cinematic classics. Moreover, the key scene of The Unvanquished stands today for the Babii Iar massacre. In a remarkable Russian documentary about Holocaust survivors, Children from the Abyss (2000, dir. Pavel Chukhrai), the scene from The Unvanquished is used as a substitute for missing archival footage of the mass execution in Babii Iar. Thus, despite its historical inaccuracy, this scene constitutes a source of visual memory for audiences both in Russia (where this documentary was broadcast on the state TV channel) and worldwide (Children from the Abyss was a part of the TV mini-series Broken Silence, produced by Steven Spielberg and widely circulated). In the same way in which the storming of the Winter Palace in Eisenstein's October (1927) became an iconic image of the Russian Revolution, the execution scene in The Unvanquished is becoming an iconic image of the Holocaust in Russia. 


\section{Notes}

1 This article is a version of previously published chapter "How a Soviet Novel Tuned into a Jewish Film: The First Depiction of the Holocaust on Soviet Screens, The Unvanquished (1945)," in Olga Gershenson, The Phantom Holocaust: Soviet Cinema and Jewish Catastrophe (New Brunswick: Rutgers University Press, 2013), 40-57.

2 Miron Markovich Chernenko, Krasnaia zvezda, zheltaiazvezda: Kinematograficheskaia istoriia evreistva $v$ Rossii, 1919-1999 (Moscow: Tekst, 2006).

3 Jeremy Hicks, "Confronting the Holocaust: Mark Donskoi's The Unvanquished" Studies in Russian and Soviet Cinema 3.1 (2009): 47.

4 Elena Baraban, "Semeinyj krug: traktovka rodstva, evreev i voennoplennyh v stalinskom kino o voine," Ab Imperio 3 (2009): 476.

5 According to many sources on the Russian Internet, The Unvanquished received a Golden Medal at the Biennale (e.g. http://russiancinema.ru/template.php?dept_ id=15\&e_dept_id=6\&text_element_id=37 [accessed October 30, 2013]). However, according to the archives of the Venice Biennale The Unvanquished did not receive any official prizes.

6 Karel C. Berkhoff, “'Total Annihilation of the Jewish Population': The Holocaust in the Soviet Media, 1941-45," Kritika 10.1 (2009): 477-504. Kiril Feferman, Soviet Jewish Stepchild: The Holocaust in the Soviet Mindset, 1941-1964 (Saarbrücken, Germany: VDM Verlag Dr. Müller, 2009).

7 Feferman, Soviet Jewish Stepchild, 27.

8 Berkoff, “Total Annihilation," 93.

9 Feferman, Soviet Jewish Stepchild, 44.

10 Boris Leont'evich Gorbatov, “Nepokorennye (Sem'ia Tarasa)," Pravda, May 17, 19, 20, 21, 22, 23; September 25, 26, 27, 30; October 2, 3, 4, 6, 7, 8, 9, 10, 11, 1943.

11 For a detailed recollection of this anecdote, see Oleg Iakubovich, "Voennye fil'my Marka Donskogo," in Kino i vremia, vol. 4 (Moscow: Iskusstvo, 1965), 92.

12 Mark Semenovitch Donskoi, "My Work on the Film Unvanquished," Cinema Chronicle 10 (1945): 9-16. Thanks to Jeremy Hicks for sharing this document with me.

13 Hicks, "Confronting the Holocaust," 41-43.

14 Thanks to Jeremy Hicks, who drew my attention to the composite nature of the execution representation in the film.

15 To watch this scene (with English subtitles), see www.phantomholocaust.org.

16 Anne Nesbet, Savage Junctures: Sergei Eisenstein and the Shape of Thinking (London; New York: I.B. Taurus, 2003), 173.

17 Milena Musina, "Ischislenie Roda," Kinovedcheskie zapiski 51 (2001): 197.

18 See also Hicks, "Confronting the Holocaust," 43.

19 According to the memoirs of Zuskin's daughter: Alla Zuskin-Perel'man, Puteshestvie Veniamina (Moscow: Gesharim, 2002), 262.

20 Zinovii Tolkatchev, who was ethnically Jewish, served as an official artist of the Red Army, attached to the forces liberating Majdanek and later Auschwitz. Tolkatchev depicted terrible scenes he witnessed in the camps. 
21 The Unvanquished is not unique in that regard. Judith Doneson notes that many Holocaust films portray Jews as feminine to express weakness and victimization. Annete Insdorf adds that with the same purpose Jews are also portrayed as children. Judith Doneson, "The Jew as a Female Figure in Holocaust Film," Shoah: A Review of Holocaust Studies and Commemorations 1.1 (1978): 11. Annette Insdorf, Indelible Shadows: Film and the Holocaust (Cambridge and New York: Cambridge University Press, 2003), 77-92.

22 The Artistic Council of the Film Committee was at the time a new organ, established in 1944 in order to "elevate the quality of films" and to ensure that the films are "wholesome aesthetically and of the highest ideological content" (Valerii Ivanovich Fomin, Kino na voine: dokumenty i svidetel'stva [Moscow: Materik, 2005], 431). The Council was entrusted with screening the scripts and approving the films for mass release, and as such it had a censorship function.

Shostakovich remained silent during the meeting, but years later, in 1961, he set a part of his Thirteenth symphony to the words of Evgenii Evtushenko's poem "Babii Iar."

Rossiiskii Gosudarstvennyi Arkhiv Literatury i Iskusstva (RGALI) f. 2456 (Komitet po delam kinematografii pri SNK SSSR, Ministerstvo kinematografii SSSR), op. 1, d. 1056 (Stenogramma, protocol i zakluchenie zasedania khudozhestvennogo soveta pri komitete po delam kinematografii po fil'mu Nepokorennye). Here as elsewhere the translations are mine.

RGALI f. 2456, op. 1, d. 1056. Mikhail Romm, Kakv kino: ustnye rasskazy (Nizhnii Novgorod: Dekom, 2003), 12034.

RGALI f. 2456, op. 1, d. 1056.

Il'ia Grigor'evich Ehrenburg, "Pomnit'!" Pravda, December 17, 1944, 3. Cited in Berkhoff, "Total Annihilation," 70.

Feferman, Soviet Jewish Stepchild, 44.

Fomin, Kino na voine, 550-551.

RGALI f. 2456, op. 1, d. 1056.

Ibid.

Ibid.

Ibid.

Ibid.

Iurii Morozov and Tatiana Derevianko, Evreiskie kinemotagrafisty v Ukraine, 19171975 (Kiev: Duch i Litera, 2004), 174.

RGALI f. 2456, op. 1, d. 1056. 
43 Ibid.

44 Fomin, Kino na Voine, 537.

45 RGALI f. 2456, op. 1, d. 1056.

46 S. Burov, "Nepokorennye," Sovetskoe iskusstvo, October 26, 1945, 2.

47 D. Kalm, “Nepokorennye," Moskovskii bol'shevik, October 21, 1945.

48 N. Zhdanov, "Nepokorennye," Izvestiia, October 23, 1945; M. Beliavskii, "Nepokorennye," Vecherniaia Moskva, October 22, 1945, 3; M. Ilushin, "Nepokorennye," Trud, October 21, 1945, 2.

49 S. Borzenko, "Nepokorennye," Pravda, October 24, 1945.

50 A. Kamenogorskii, "Nepokorennye," Moskovskii komsomolets, October 20, 1945, 3; A. P. Shtein, "Nepokorennye," Krasnyi flot, October 21, 1945.

51 I. Sokolov, “O Neprimirimykh i Nepokorennykh," Komsomolskaia pravda, October 21, 1945.

52 I. Kruti, “Nepokorennye na ekrane," Literaturnaia gazeta, October 20, 1945.

53 Hicks demonstrates that at least in Moscow and Kiev the film was shown in theaters for less than two months ("Confronting the Holocaust," 45).

54 Iakubovich, "Voennye fil'my Marka Donskogo," 99.

55 I. G. Bol'shakov, Sovetskoe iskusstvo v Gody Velikoi Otechestvennoi voiny, 1941-1945 (Moscow: Goskinoizdat, 1948), 51-52.

56 Ibid.

57 For analysis of the Holocaust representation on Soviet screens throughout the Soviet era, see Gershenson, Phantom Holocaust.

58 Iakubovich, “Voennye fil'my Marka Donskogo," 100. 